\title{
PEMANFAATAN PEKARANGAN UNTUK BUDIDAYA ANGGUR DENGAN MEDIA CAMPURAN BIOCHAR
}

\author{
Susila Herlambang', Danang Yudhiantoro², Astrid Wahyu Adventri \\ Wibowo3 \\ ${ }^{1}$ Jurusan Agroteknologi, Fakultas Pertanian (Universitas Pembangunan Nasional \\ Yogyakarta) \\ 2Jurusan Manajemen, Fakultas Ekonomi Bisnis (Universitas Pembangunan Nasional \\ Yogyakarta) \\ 3Jurusan Teknik Industri, Fakultas Teknik Industri (Universitas Pembangunan \\ Nasional Yogyakarta) \\ ${ }^{1}$ E-mail address susilaherlambang@upnyk.ac.id; \\ 2 E-mail address danang.yudhiantoro@upnyk.ac.id; \\ 3 E-mail address astrid.wahyu@upnyk.ac.id
}

\begin{abstract}
The Covid-19 pandemic has significant socio-economic impacts for all regions in Indonesia, one of which is in Bantul Regency. In anticipation of this impact, Mayungan Hamlet government officials and the community service team made several programs related to the development of grape cultivation in their home yard. With this activity, it is hoped that the community will be able to improve the family economy which was originally declining. The series of activities carried out were mapping of village potentials, outreach, practice, mentoring, and technical guidance. This activity was chosen in order to make it easier for the community to accept new technology with the formulation of planting media made from compost and coconut shell biochar. The obstacle faced during the service was that all activities were carried out during a pandemic where there were restrictions on community activities so that not all participated in this activity. However, all activities were successfully carried out, as evidenced by the 14 invited community representatives, all of whom were present in every activity and there was an increase in community (cognitive) knowledge about grape cultivation.
\end{abstract}

Keywords: community service, grape cultivation, biochar, home yard

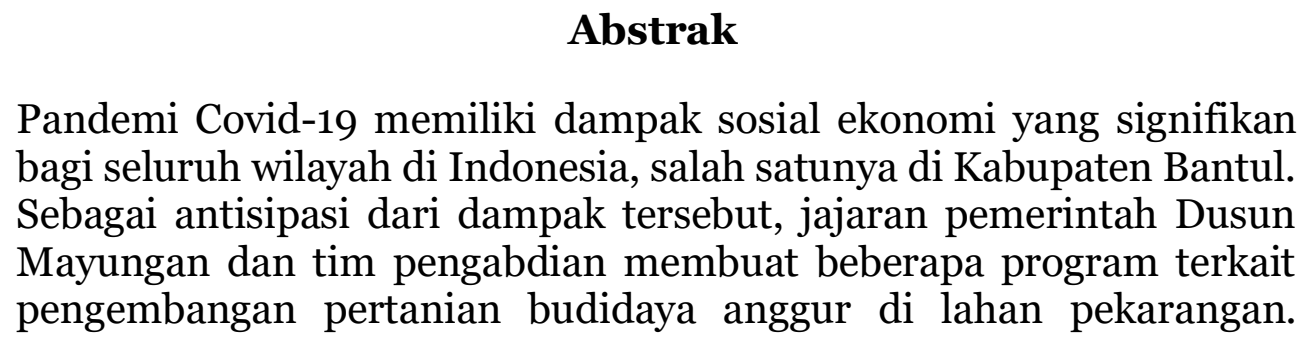


Dengan adanya kegiatan ini diharapkan masyarakat dapat meningkatkan kembali perekonomian keluarga yang semula menurun. Rangkaian kegiatan yang dilakukan adalah pemetaan potensi desa, sosialisasi, penyuluhan, praktik, pendampingan, dan bimbingan teknis (bimtek). Kegiatan ini dipilih supaya memudahkan masyarakat dalam menerima teknologi baru dengan formulasi media tanam berbahan kompos dan biochar tempurung kelapa. Kendala yang dihadapi selama pengabdian berlangsung adalah seluruh kegiatan dilaksanakan ketika pandemi dimana terjadi pembatasan kegiatan masyarakat sehingga tidak semua turut berpartisipasi dalam kegiatan ini. Namun, seluruh kegiatan berhasil dilaksanakan terbukti dari 14 perwakilan masyarakat yang diundang, seluruhnya hadir dalam setiap kegiatan dan terjadi peningkatan pengetahuan (kognitif) masyarakat mengenai budidaya anggur.

Kata Kunci: pengabdian masyarakat, budidaya anggur, biochar, pekarangan rumah

\section{PENDAHULUAN}

Pandemi Covid-19 yang belum mengalami penurunan jumlah kasus positif menyebabkan ketidakstabilan perekonomian dan berdampak pada aspek psikologi bagi masyarakat Mayungan, Potorono, Banguntapan, Bantul, Yogyakarta. Masyarakat banyak mengalami penurunan aktivitas dan penghasilan serta kehilangan pekerjaan pokok sehingga mengakibatkan perekonomian keluarga menurun. Desa Potorono secara geografis terletak pada 110 25' 52" BT dan 7 50'56 "LS, atau sebelah tenggara Kota Yogyakarta dengan jarak $9 \mathrm{~km}$ dari pusat Kota Yogyakarta. Desa Potorono mempunyai luas wilayah 3,90 km2 di Pedukuhan Salakan Potorono terdapat 1563 orang. Potensi wilayah di bagian tengah wilayah desa dilewati oleh Sungai
Mruwe yang debit airnya cukup besar, stabil, dan digunakan untuk keperluan irigasi pertanian, rumah tangga, serta budidaya perikanan pada daerah sekitarnya. Selain itu, di tepi Sungai Mruwe, tepatnya di Pedukuhan Salakan, terdapat Wanadesa (hutan) dan Telaga Desa Potorono. Wanadesa dan Telaga Desa Potorono ini juga dijadikan sebagai objek wisata dan cukup banyak wisatawan yang datang karena mudah dijangkau. Batas wilayah desa Potorono berada pada:

Sebelah Utara berbatasan dengan Desa Baturetno, Banguntapan, Bantul dan

Desa Sendangtirto, Berbah, Sleman. Sebelah Timur berbatasan dengan Desa Sitimulyo, Piyungan, Bantul. Sebelah Selatan berbatasan dengan Desa Jambidan, Banguntapan, Bantul dan 
Desa Wirokerten, Banguntapan, Bantul. Sebelah Barat berbatasan dengan

Desa Baturetno, Banguntapan, Bantul dan Desa Wirokerten, Banguntapan, Bantul.

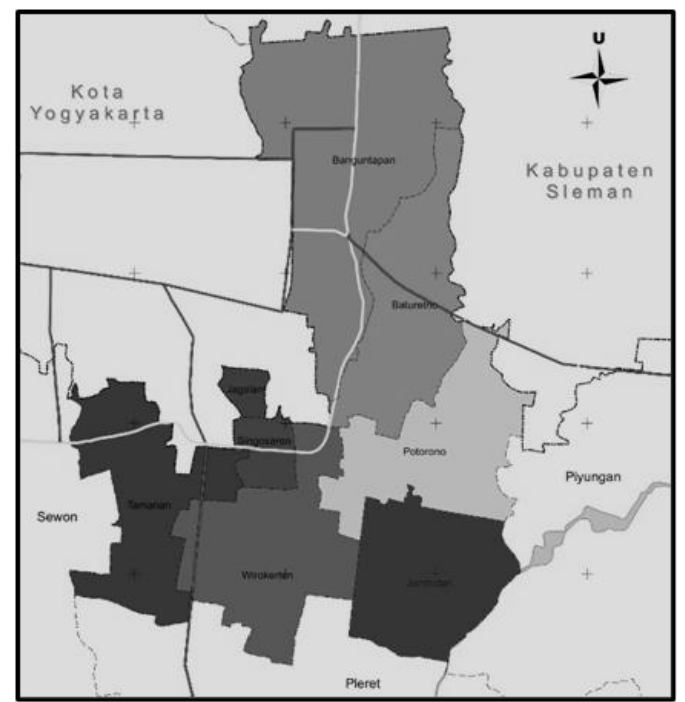

Gambar 1. Peta Wilayah Kecamatan Banguntapan (Pemerintah Kabupaten Bantul, 2021)

Dusun Mayungan merupakan mitra kerja sama karena berdasarkan pada

pengamatan telah terbentuk rumah kompos dari pengumpulan limbah rumah tangga kapasitas 1,5 ton per minggu dan mempunyai bank sampah desa. Pengembangan potensi dusun dengan budidaya tanaman anggur di lahan pekarangan dengan media kompos dan biochar tempurung kelapa, merupakan salah satu solusi dalam peningkatan psikologi masyarakat dan perekonomian keluarga di saat pandemi Covid-19. Pemanfaatan pekarangan untuk budidaya tanaman dinilai dapat memberikan penghasilan tambahan (Suwarno et al., 2018) serta meningkatkan kecukupan, ketahanan, dan kemandirian pangan masyarakat (Djuwendah et al., 2021).

Penerapan limbah organik peruntukan media tanam merupakan sinergi antara perekonomian keluarga dan lingkungan. Potensi yang dimiliki dusun ini menjadi pilihan yang strategis untuk unit percontohan dalam analisis dan pengembangan budidaya anggur dilahan pekarangan keluarga. Penggunaan pupuk organik kompos dengan memadukan biochar tempurung kelapa merupakan upaya meningkatkan ketersediaan hara tanaman dilahan pekarangan. Teknologi campuran media diharapkan dapat meningkatkan efisiensi biaya pertanian dan produktivitas budidaya tanaman anggur.

Atas dasar tersebut diperlukan penguatan ekonomi lokal di era pandemi Covid-19 melalui pengembangan pertanian budidaya anggur di lahan pekarangan sehingga diharapkan dalam jangka panjang akan menciptakan sinergitas yang positif antara masyarakat petani (pro job), industri (pro growth) dan pemerintah daerah setempat (pro poor) menjadi kawasan dusun anggur. 


\section{METODE DAN PELAKSANAAN}

\section{Metode}

Pada program pengabdian kepada masyarakat ini rangkaian kegiatan yang dilakukan adalah pemetaan potensi desa, sosialisasi, penyuluhan, praktik, pendampingan, dan bimbingan teknis (bimtek). Kegiatan ini dipilih supaya memudahkan masyarakat dalam menerima teknologi baru dengan formulasi media tanam berbahan kompos dan biochar tempurung kelapa. Di tahap awal dilakukan pemetaan potensi desa, tim pengabdian melakukan identifikasi terhadap potensi dan limitasi yang dihadapi oleh masyarakat Desa Mayungan.

Teknologi pemanfaatan limbah organik yang dikomposkan dengan biochar tempurung kelapa merupakan teknologi ramah lingkungan yang sangat berpotensi di lokasi ini.
Pemanfaatan limbah ini dijadikan media tanam anggur di lahan pekarangan padat penduduk. Metode yang digunakan adalah ceramah dan diskusi guna memberikan bahan materi tentang teknologi formulasi media tanam untuk tanaman anggur yang berbasis ramah lingkungan.

Kemudian dilakukan pembagian bibit anggur bagi masyarakat Desa Mayungan, kegiatan ini dimaksudkan supaya masyarakat dapat mempraktikan penanaman anggur dengan media tanam campuran biochar di pekarangan rumah masing-masing. Untuk menjaga kualitas, kuantitas praktek, dan keberlanjutanya dilakukan pendampingan serta bimbingan teknis (bimtek) secara berkala. Kegiatan ini bertujuan supaya masyarakat dapat mandiri dalam pengelolaan limbah rumah tangga, mengelola sanitasi lingkungan, dan penanaman anggur.
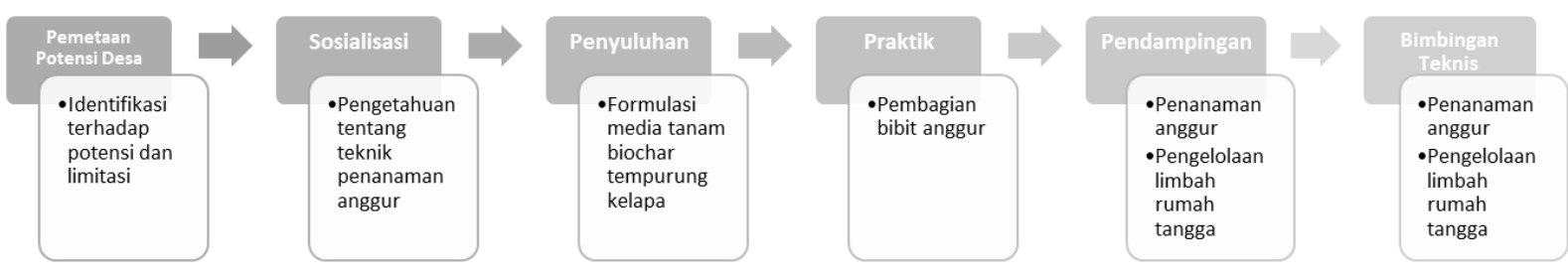

Gambar 2. Alur Kegiatan Pengabdian kepada Masyarakat

Mitra rumah kompos yang mengerakan masyarakat desa dalam beranggotakan 118 kepala keluarga dengan kapasitas 1,5 ton per minggu sangat menanti kehadiran dan partisipasi dari perguruan tinggi untuk meningkatkan perekonomian yang bersifat ramah lingkungan dengan budidaya tanaman anggur di pekarangan. 


\section{Pelaksanaan Kegiatan}

Rangkaian kegiatan, berupa sosialisasi, penyuluhan, praktek, pendampingan dan bimtek, di mulai pada tanggal 2 Mei 2021 dilakukan di Desa Mayungan, Potorono, Banguntapan, Bantul. Tema untuk kegiatan sosialisasi dan penyuluhan adalah terkait dengan formulasi media tanam biochar tempurung kelapa dan

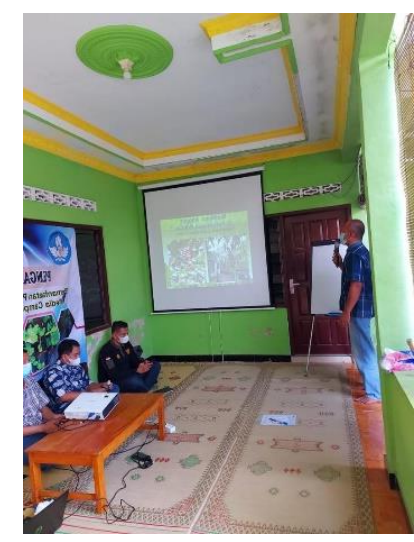

(a)

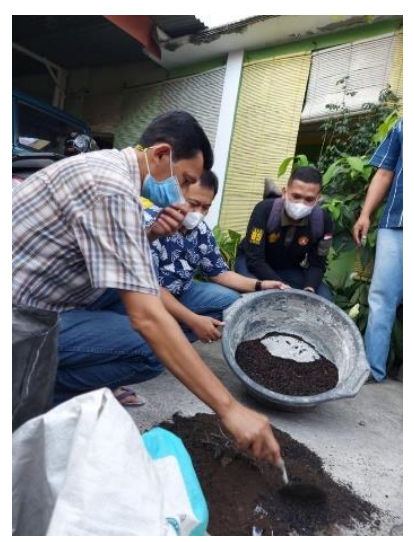

(b) pengetahuan tentang budidaya anggur, sehingga produk pupuk organik dari rumah kompos yang telah dimiliki oleh Desa Mayungan akan efektif dalam budidaya tanaman anggur pada lahan sempit. Seluruh kegiatan berhasil dilaksanakan terbukti dari 14 perwakilan masyarakat yang diundang, seluruhnya hadir dalam setiap kegiatan.

Gambar 3. Kegiatan pengabdian (a) sosialisasi (b) penyuluhan (c) pembagian bibit

HASIL DAN PEMBAHASAN

\section{Hasil}

Pandemi Covid-19 memiliki dampak sosial ekonomi yang signifikan bagi seluruh wilayah di Indonesia, salah satunya di Kabupaten Bantul. Berdasarkan data Pemerintah Kabupaten Bantul (2020) dampak tersebut meliputi:

- Kegiatan perdagangan, industri, dan pariwisata mengalami penurunan

- Aktivitas masyarakat

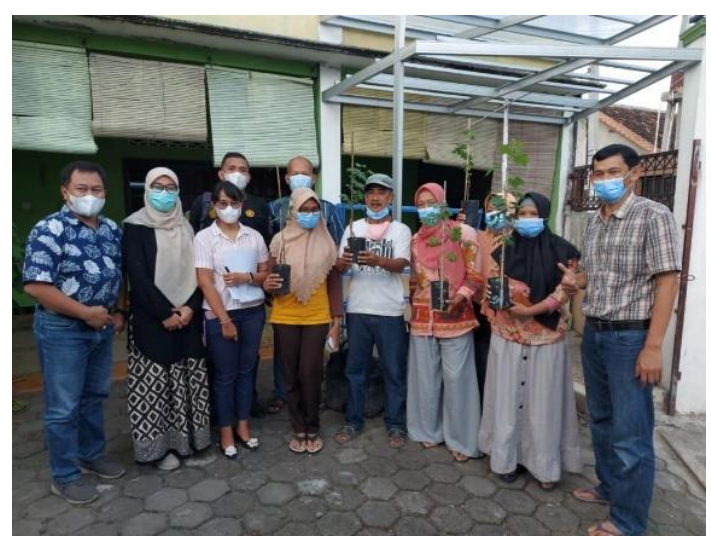

(c) 
- Ketimpangan gender semakin tinggi (pembagian peran keluarga terganggu)

Sebagai antisipasi dari dampak pandemi Covid-19, jajaran pemerintah Dusun Mayungan dan tim pengabdian membuat beberapa program terkait pengembangan pertanian budidaya anggur di lahan pekarangan. Dengan adanya kegiatan ini diharapkan masyarakat dapat meningkatkan kembali perekonomian keluarga yang semula menurun.

\section{Pembahasan}

Pada tahap pemetaan potensi desa terbagi menjadi dua sub-kegiatan, yaitu kunjungan ke Kepala Dusun Mayungan dan kunjungan ke masyarakat. Tim pengabdi mengidentifikasi beberapa temuan diantaranya di dusun tersebut telah terbentuk rumah kompos dari pengumpulan limbah rumah tangga dengan kapasitas 1,5 ton per minggu, mempunyai bank sampah desa, dan masyarakat memiliki sedikit pekarangan terbuka di area rumah. Dari kondisi-kondisi tersebut, maka ditindaklanjuti dengan serangkaian kegiatan untuk pengembangan potensi dusun dengan budidaya tanaman anggur di lahan pekarangan dengan media kompos dan biochar tempurung kelapa sebagai upaya untuk meningkatan psikologi masyarakat dan perekonomian keluarga di saat pandemi Covid-19. Rangkaian kegiatan yang telah dilaksanakan adalah sosialisasi terkait pengetahuan terkait teknik penanaman anggur, penyuluhan tentang formulasi media tanam biochar tempurung kelapa, praktek penanaman dan pembagian bibit anggur, hingga pendampingan dan bimtek penanaman anggur.

Tanaman anggur ini dipilih karena karakteristiknya yang mudah beradaptasi dengan jenis tanah apapun, seperti tanah berpasir hingga tanah liat berat (Rombough, 2002) sehingga diharapkan memudahkan masyarakat dalam milih media tanam. Dalam sosialisasi telah dijelaskan tentang teknik-teknik penanaman anggur kepada masyarakat Dusun Mayungan. Untuk bibit anggur sendiri relatif mudah untuk dibuat, yaitu dengan cara mencangkok dan teknik tempel. Sebelum proses pencangkokan dimulai, masyarakat dipastikan untuk memilih pohon anggur yang memiliki kualitas unggul dan tidak berpenyakit. Kemudian dilakukan pencangkokan pada bagian batang anggur yang tegak sehingga bibit mudah untuk ditanam. Selama proses penanaman, lahan juga harus dijaga kebersihannya dari gulma 
dan penyiraman dilakukan 3 hari sekali atau ketika media tanam sudah mulai kering. Hal yang tak kalah penting dalam budidaya anggur adalah pengelolaan hama. Masing-masing hama memiliki cara penanganan yang berbeda. Kutu phylloxera (Phylloxera vitifoliae) adalah hama yang akan menghisap cairan akar dan daun sehingga akan terbentuk bisul-bisul kecil pada daun dan akar akan membengkak seperti kutil. Hal ini akan membuat tanaman anggur tumbuh kerdil, layu, dan buah sedikit. Cara memberantasnya adalah dengan memangkas tanaman yang terserang dan kemudian dibakar. Jika tanaman anggur terkena hama tungau merah (Tetranychus sp.) gejala yang akan muncul ialah adanya bercak-bercak kuning pada daun dan berbuah hitam. Ulat kantong (Mahasena corbetti) adalah salah satu jenis hama yang memakan bagian atas permukaan daun sehingga terjadi lubang-lubang kecil pada daun. Cara pengendalian hama jenis ini adalah dengan memangkas dan memotong tanaman yang terserang dan kemudian dibakar.

Faktor yang mempengaruhi pertumbuhan tanaman terdiri dari faktor internal dan faktor eksternal (Gunadi \& Sumiartha, 2019). Faktor internal berasal dari pada bibit, benih, atau tanaman itu sendiri sedangkan faktor eksternal adalah faktor yang berasal dari luar bibit, benih, atau tanaman, salah satunya adalah media tanam. Maka dari itu dilaksanakan penyuluhan terkait formulasi media tanam. Media tanam yang digunakan berupa tanah, biochar tempurung kelapa, dan kompos atau pupuk kandang. Untuk kompos sendiri masyarakat Dusun Mayungan sudah dapat menyediakannya secara mandiri karena telah memiliki rumah kompos dengan kapasitas yang besar. Media tanam juga dicampurkan dengan biochar. Biochar merupakan sebuah bahan padat yang kaya akan karbon dan sebagai hasil konversi dari limbah atau sampah organik (biomas pertanian) melalui pyrolysis (Nurida et al., 2015). Biochar juga dikenal sebagai arang hayati dengan kandungan karbon hitam berasal dari biomassa, proses biochar melalui pembakaran pada temperatur $<700^{\circ} \mathrm{C}$ dalam kondisi oksigen yang terbatas menghasilkan bahan organik dengan konsentrasi karbon 70-80\% (Lehmann \& Joseph, 2012). Di beberapa penelitian dapat dikonfirmasi bahwa pengaplikasian biochar di dalam tanah memiliki berbagai macam keuntungan yang berkaitan dengan perbaikan kualitas tanah.

Keuntungan-keuntungan 
tersebut adalah: (1) menstimulasi simbiosis fiksasi nitrogen pada legum; (2) meningkatkan fungi mikoriza arbuscular, (3) meningkatkan struktur tanah; (4) meningkatkan efesiensi pemupukan; (5) meningkatkan kapasitas tukar kation (KTK); (6) meningkatkan daya ikat air (water holding capacity); (7) meningkatkan biomassa mikroba tanah; meningkatkan respirasi mikroba tanah; (9) menurunkan gas $\mathrm{CH}_{4}$ dan $\mathrm{N}_{2} \mathrm{O}$ yang terlepas ke udara; (10) menurunkan kemasaman tanah; dan (11) mengurangi keracunan aluminium (Herlambang et al., 2020). Biochar dalam tanah tidak dapat menggantikan peranan pupuk sehingga penambah jumlah nitrogen dan unsur hara lain yang diperlukan dalam meningkatkan hasil tanaman. Pemberian pupuk kandang atau kompos pada budidaya anggur tergolong efektif (Wibawa et al., 2020).

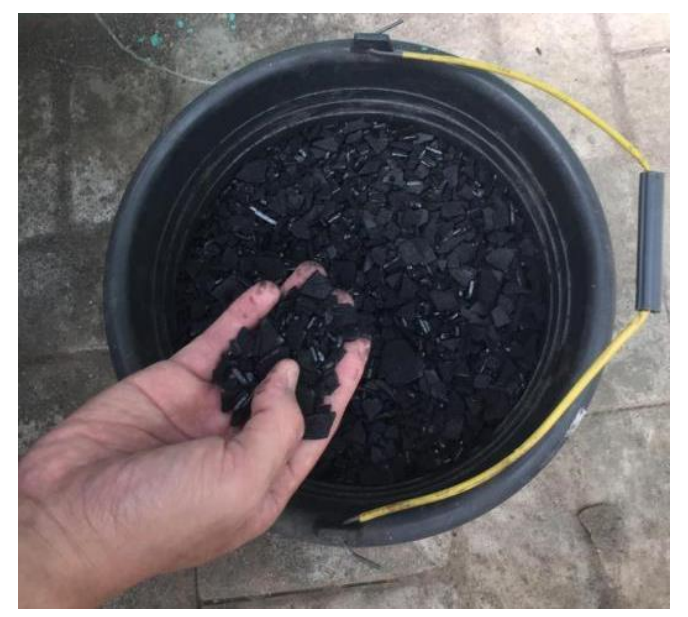

Gambar 4. Biochar Tempurung Kelapa Kasar

Kemudian dilakukan pembagian bibit anggur bagi masyarakat Desa Mayungan, kegiatan ini dimaksudkan supaya masyarakat dapat mempraktikan penanaman anggur dengan media tanam campuran biochar di pekarangan rumah masing-masing. Untuk menjaga kualitas, kuantitas praktek, dan keberlanjutanya dilakukan pendampingan serta bimbingan teknis (bimtek) secara berkala. Kegiatan ini bertujuan supaya masyarakat dapat mandiri dalam pengelolaan limbah rumah tangga, mengelola sanitasi lingkungan, dan penanaman anggur.

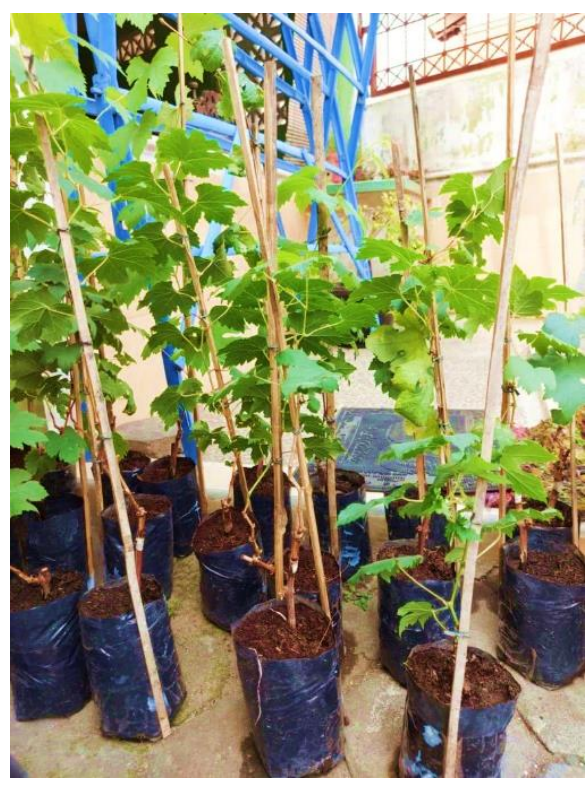

Gambar 5. Bibit Anggur yang Dibagikan kepada Masyarakat Dusun Mayungan

Serangkaian kegiatan pengabdian yang dilakukan telah mampu memberikan perubahan bagi 
individu/masyarakat. Masyarakat di Dusun Mayungan memiliki aktivitas lain berupa budidaya anggur di pekarangan rumah sebagai upaya untuk meningkatan psikologi masyarakat dan perekonomian keluarga di saat pandemi Covid-19. Kendala yang dihadapi selama pengabdian berlangsung adalah seluruh kegiatan dilaksanakan ketika pandemi dimana terjadi pembatasan kegiatan masyarakat sehingga tidak semua turut berpartisipasi dalam kegiatan ini. Namun, seluruh kegiatan berhasil dilaksanakan terbukti dari 14 perwakilan masyarakat yang diundang, seluruhnya hadir dalam setiap kegiatan.

\section{PENUTUP}

\section{Simpulan}

Kegiatan pengabdian kepada masyarakat dapat terselenggara dengan baik dan memberikan dampak sesuai yang diharapkan. Hal ini dapat dilihat dari aspek peningkatan ilmu (kognitif) masyarakat mengenai budidaya anggur.

\section{Saran}

Pada proses pendampingan dan bimtek terkait penanaman anggur di pekarangan rumah masih berlangsung mengingat masa panen anggur yang lama yaitu 9 bulan (Wium, 2008). Sehingga disarankan tim pengabdian masih harus memantau penanaman anggur di masyarakat Dusun Mayungan .

\section{UCAPAN TERIMA KASIH}

Penulis mengucapkan terima kasih kepada Lembaga Penelitian dan Pengabdian kepada Masyarakat Universitas Pembangunan Nasional Veteran Yogyakarta, Indonesia yang telah memberikan dukungan dana untuk pengabdian ini. Ucapan terima kasih disampaikan kepada pihak-pihak yang telah berkontrubisi positif pada pengabdian masyarakat dengan menjelaskan bentuk kontribusi yang telah diberikan.

\section{DAFTAR PUSTAKA}

Djuwendah, E., Karyani, T., Saidah, Z., \& Hasbiansyah, O. 2021. Pelatihan Budidaya Sayuran Secara Vertikultur di Pekarangan Guna Ketahanan Pangan Rumah Tangga. Dinamisia: Jurnal Pengabdian Kepada Masyarakat, 5(2), 349-355. https://doi.org/10.31849/dinamis ia.v5i2.5291

Gunadi, I. G. A., \& Sumiartha, I. K. 2019. Pertumbuhan Bibit Anggur Prabu Bestari Asal Okulasi pada Berbagai Campuran dan 
Kandungan Air Media Tanam. AGROTROP, 9(1), 42-55.

Herlambang, S., Purwono, A. Z., Gomareuzzaman, M., \& Wibowo, A. W. A. 2020. Biochar: Salah Satu Alternatif untuk Perbaikan Lahan dan Lingkungan. LPPM UPN "Veteran" Yogyakarta.

Lehmann, J., \& Joseph, S. 2012. Biochar for environmental management: An introduction. In Biochar for Environmental Management: Science and Technology (Vol. 1, pp. 1-12). https://doi.org/10.4324/9781849 770552

Nurida, N. L., Rachman, A., \& Sutono, S. 2015. Biochar Pembenah Tanah yang Potensial (Y. Soelaeman \& J. Purnomo (eds.)). IAARD Press. https://doi.org/10.1017/CBO9781 107415324.004

Pemerintah Kabupaten Bantul. 2020. Dampak dan Upaya Pemulihan Sosial Ekonomi Masyarakat di Kabupaten Bantul Akibat Covid19. Pemerintah Kabupaten Bantul. Pemerintah Kabupaten Bantul. 2021. Profil Kecamatan Banguntapan. Pemerintah Kabupaten Bantul. https://kecbanguntapan.bantulkab.go.id/hal /profil
Rombough, L. 2002. The grape grower: A guide to organic viticulture. Chelsea Green Publishing.

Suwarno, E., Suhesti, E., \& Nahlunnisa. 2018.

Pengembangan

Agroforestry Sederhana Di Sekitar Rumah. Dinamisia: Jurnal Pengabdian Kepada Masyarakat, 2(2), $\quad 113-120$. https://doi.org/10.31849/dinamis ia.v2i2.1255

Wibawa, G. M. S., Agung, I. D. G., \& Suamba, I. K. 2020. Efektivitas Penggunaan Faktor Produksi Usahatani Anggur di Desa Kalianget , Kecamatan Seririt , Kabupaten Buleleng. Jurnal Agribisnis Dan Agrowisata, 9(1), 89-98.

Wium, D. 2008. The Complete Grape Growers Guide. 